\title{
Molecular phylogenetic relationships among members of the family Phytolaccaceae sensu lato inferred from internal transcribed spacer sequences of nuclear ribosomal DNA
}

\author{
J. Lee' ${ }^{1}$, S.Y. Kim ${ }^{1}$, S.H. Park ${ }^{1}$ and M.A. Ali ${ }^{2}$ \\ ${ }^{1}$ International Biological Material Research Center, \\ Korea Research Institute of Bioscience and Biotechnology, \\ Yuseong-gu, Daejeon, South Korea \\ ${ }^{2}$ Department of Botany and Microbiology, College of Science, \\ King Saud University, Riyadh, Saudi Arabia \\ Corresponding author: M.A. Ali \\ E-mail: ajmalpdrc@gmail.com
}

Genet. Mol. Res. 12 (4): 4515-4525 (2013)

Received August 6, 2012

Accepted November 21, 2012

Published February 28, 2013

DOI http://dx.doi.org/10.4238/2013.February.28.15

\begin{abstract}
The phylogeny of a phylogenetically poorly known family, Phytolaccaceae sensu lato (s.l.), was constructed for resolving conflicts concerning taxonomic delimitations. Cladistic analyses were made based on 44 sequences of the internal transcribed spacer of nuclear ribosomal DNA from 11 families (Aizoaceae, Basellaceae, Didiereaceae, Molluginaceae, Nyctaginaceae, Phytolaccaceae s.l., Polygonaceae, Portulacaceae, Sarcobataceae, Tamaricaceae, and Nepenthaceae) of the order Caryophyllales. The maximum parsimony tree from the analysis resolved a monophyletic group of the order Caryophyllales; however, the members, Agdestis, Anisomeria, Gallesia, Gisekia, Hilleria, Ledenbergia, Microtea, Monococcus, Petiveria, Phytolacca, Rivinia,
\end{abstract}


Schindleria, Seguieria, Stegnosperma, and Trichostigma, which belong to the family Phytolaccaceae s.l., did not cluster under a single clade, demonstrating that Phytolaccaceae is polyphyletic.

Key words: Phytolaccaceae; Phylogenetic relationships; Internal transcribed spacer; Nuclear ribosomal DNA

\section{INTRODUCTION}

The Caryophyllales (part of the core eudicots), sometimes also called Centrospermae, include about $6 \%$ of dicotyledonous species and comprise 33 families, 692 genera and approximately 11200 species. The monophyly of the Caryophyllales has been previously supported by DNA sequences, cytochrome $\mathrm{c}$ sequence data and heritable characters such as anther wall development and vessel elements with simple perforations (Downie et al., 1997; Cuenoud et al., 2002).

Caryophyllales sensu stricto (s.s.), have long been identified as a natural assemblage of families. Morphological characters diagnostic of the group include free-central (sometimes basal) placentation, perisperm, and curved embryos (Bittrich, 1993). Studies on pigment chemistry (Clement et al., 1994) have shown that all Caryophyllales families, except Caryophyllaceae and Molluginaceae, produce betalain pigments instead of anthocyanins (as is the case in the rest of flowering plants). Studies on the ultrastructure of sieve-element plastids have revealed that the Caryophyllales share a unique type (P3; Behnke, 1994), which is characterized by a peripheral ring of proteinaceous filaments, generally surrounding a protein crystal of either globular or angular shape. Cronquist and Thorne (1994), in summarizing the data available on Caryophyllales, excluded 7 families (Bataceae, Gyrostemonaceae, Plumbaginaceae, Polygonaceae, Rhabdodendraceae, Theligonaceae, and Vivianaceae) and listed only 11 families (Aizoaceae, Amaranthaceae, Basellaceae, Cactaceae, Caryophyllaceae, Chenopodiaceae, Didiereaceae, Molluginaceae, Nyctaginaceae, Phytolaccaceae, and Portulacaceae) under this order.

Molecular systematic studies have substantially added to our knowledge of the phylogeny of the Caryophyllales; as a result, additional families including Droseraceae, Drosophyllaceae, Nepenthaceae, Plumbaginaceae, Polygonaceae, Asteropeiaceae, Physenaceae, Ancistrocladaceae, Dioncophyllaceae, Frankeniaceae, Rhabdodendraceae, Simmondsiaceae, and Tamaricaceae have been shown to be related to the Caryophyllales, which finally led to redefining the Caryophyllales in the APG (Angiosperm Phylogeny Group, http://www.mobot.org/ mobot/research/apweb/), in which the 'non-core Caryophyllales' families listed above have been included in addition to the 'core Caryophyllales' previously recognized, for a total of 26 families. Despite the data available, uncertainties still remained as to the delimitation of several families, their phylogenetic relationships, and the placement of some enigmatic genera: Bittrich (1993) listed 6 families, i.e., Amaranthaceae, Chenopodiaceae, Portulacaceae, Nyctaginaceae, Phytolaccaceae, and Molluginaceae, that lacked clear delimitation or valid synapomorphies.

The Phytolaccaceae comprise a weedy family of largely tropical and subtropical plants that have been placed, almost without exception, in Centrospermae under the order Chenopodiales (Hutchinson, 1959) or Caryophyllales (Bessey, 1915). Economically, some species of Phytolaccaceae contain partially toxic substances which are used medicinally. The roots and fruits of some members of Phytolaccaceae contain saponin, which is utilized as soap. Because of its fast growing nature, Phytolacca dioica is frequently planted as a shade tree in the tropics. 
Nowicke (1969) reported the use of berries and the young sprouts and leaves of some species of Phytolacca as an adulterant of red wine and poke salad respectively.

The generic composition of Phytolaccaceae has long been controversial, and a synoptic review of past taxonomic treatments reveals a variable assortment of familial circumscriptions and intrafamilial classifications. Lack of agreement has characterized delimitation of Phytolaccaceae senso lato (s.1.) over the past several decades. The inclusion or exclusion of Achatocarpus, Phaulothamnus, Agdestis, Stegnosperma, and Barbeuia, often referred to as anomalous genera in Phytolaccaceae (s.l.), has been the reason for disagreement in the classification of Phytolaccaceae. The family Phytolaccaceae has undergone a continuous thinning, with the recognition of Stegnospermataceae and Achatocarpaceae in Angiosperm Phylogeny Group, and also sometimes Petiveriaceae, Agdestidaceae, Gisekiaceae and Barbeuiaceae (Nakai, 1942) as separate families.

Heimerl (1889) recognized 6 tribes, namely Rivineae [Gallesia Casar., Seguieria Loefl., Monococcus F. Muell., Phaulothamnus A. Gray, Ledenbergia Klotzsch, Rivina L., Petiveria L., Microtea Swartz, Hilleria Vell. (as Mohlana Mart.), Adenogramma Reichb.], Limeae (Polpoda Presl, Limeum L., Barbeuia Thouars), Stegnospermeae (Stegnosperma Benth., Psammotropha Eckl. \& Zey.), Phytolacceae (Phytolacca L., Anisomeria D. Don, Giesekia L.), Gyrostemoneae (Didymotheca Hook. f., Gyrostemon Desf., Tersonia Moq.), and Agdestideae (Agdestis Moc. \& Sesse). Heimerl (1889) did not consider Trichostigma A. Rich., Ercilla Juss. (Ercilia), or Schindleria H. Walter as distinct genera, and Lophiocarpus Turcz. was not treated but rather included in the Chenopodiaceae.

Walter's (1909) monograph was the first comprehensive treatment of the family Pytolaccaceae. Walter (1909) recognized two subfamilies, Phytolaccoideae containing 17 genera (Anisomeria, Ercilla, Phytolacca, Barbeuia, Didymotheca, Tersonia, Gyrostemon, Codonocarpus A. Cunn., Hilleria, Seguieria, Gallesia, Rivina, Trichostigma, Ledenbergia, Schindleria, Petiveria, and Monococcus) and Stegnospermoideae with only the one genus Stegnosperma. Agdestis which was not placed in a subfamily or tribe, plus three other anomalous genera [Achatocarpus triana (formerly placed in the Amaranthaceae by Bentham and Hooker, 1883), Microtea and Phaulothamnus] with affinities to the Chenopodiaceae were added for a total of 22 genera. Walter (1909) removed 6 genera [Limeum, Giesekia, Adenogramma, Psammotropha, Polpoda, and Semonvillea Gay, the last genus to which Heimerl (1889) treated as a subgenus of Limeum] to the subfamily Ficoideae of the Aizoaceae. In addition to this major change, Walter (1909) recognized Ercilla as distinct from Phytolacca, and Trichostigma as distinct from Rivina, and included the genus Schindleria.

In the second edition of Pflanzenfamilien, Heimerl (1934) divided the Phytolaccaceae into the 5 tribes Rivineae, Phytolacceae, Agdestideae, Stegnospermeae, and Barbeuieae, with the last three being monogeneric; in addition, Heimerl (1934) cited two genera, Microtea and Lophiocarpus, as connecting links to the Chenopodiaceae. Heimerl (1934) reduced the total number of genera to 17 by removing 6 previously included by Walter (1909) and adding Lophiocarpus, a genus formerly placed in the Chenopodiaceae (Bentham and Hooker, 1883), and placed by Brown (1909) in the Phytolaccaceae as congeneric with Microtea. There were four genera (Gyrostemon, Codonocarpus, Didymotheca, Tersonia) that Heimerl (1934) separated from the Phytolaccaceae and transferred to Gyrostemonaceae, which possess unisexual flowers and show a high carpel frequency (rarely two or one). The Achatocarpaceae was established for two dioecious genera, Achatocarpus and Phaulothamnus, found in the American tropics and subtropics. 
Hutchinson (1959) included the Phytolaccaceae in the Chenopodiales; the latter consists of 10 families of which 4 have resulted from a further division of the Phytolaccaceae. The family was consequently reduced to 3 genera, i.e., Phytolacca, Anisomeria and Ercilla. The genera Agdestis and Barbeuia were placed in monotypic families, and the remaining genera, with the exception of Stegnosperma which Hutchinson (1959) placed as a monogeneric family in the Pittosporales, comprise the Petiveriaceae (Gallesia, Hilleria, Ledenbergia, Lophiocarpus, Monococcus, Microtea, Petiveria, Rivina, Schindleria, Seguieria, Trichostigma).

Eckardt (1964) made some changes in the larger taxa, recognizing 3 subfamilies, the Phytolaccoideae with 4 tribes and the Stegnospermatoideae and Microteoideae each with a single tribe. Eckardt's (1964) treatment appears to follow closely that of Heimerl (1934).

Nowicke (1969) revised the family Phytolaccaceae utilizing pollen morphology in addition to floral and vegetative morphology. Nowicke (1969) recognized 17 genera (Anisomeria, Ercilla, Phytolacca, Gallesia, Seguieria, Rivinia, Trichostigma, Schindleria, Hilleria, Petiveria, Ledenbergia, Monococcus, Agdestis, Microtea, Lophiocarpus, Stegnosperma, and Barbeuia) and placed them in 6 subfamilies (Phytolaccoideae, Rivinoideae, Agdestioideae, Microteoideae, Stegnospermoideae, and Barbeuioideae), three of which were newly established, with all subfamilies except the Rivinoideae (with Seguierieae and Rivineae). Brown and Varadarajan (1985) classified Phytolaccaceae s.l., into Phytolaccaceae s.s., Petiveriaceae and Achatocarpaceae and three more monogeneric families, namely Agdestidaceae, Barbeuiaceae and Stegnospermaceae.

The genera Achatocarpus, Agdestis, Barbeuia, Phaulothamnus, and Stegnosperma are so-called anomalous phytolaccaceous members. Additional but less widespread disagreement concerns the placement of Lophiocarpus and Microtea. Extremes in the spectrum of treatments for the family range from the 'sensu lato' delimitations of Heimerl (1889), Cronquisat (1968), and Thorne (1976) to the 'sensu stricto' of Hutchinson $(1959,1973)$. The remaining treatments (Walter, 1909; Heimerl, 1934; Nowicke, 1969; Takhtajan, 1969, 1980; Bortenschlager, 1973; Dahlgren, 1977, 1980; Cronquist, 1981; Thorne, 1981; Brown and Varadarajan, 1985) can be considered to be 'modified sensu lato', where one or more segregate families are extracted from Phytolaccaceae (s.1.).

Taking the aforementioned taxonomic history (from the phylogeny of Caryophyllales to the series of taxonomic treatment of Phytolaccaceae s.l.) and the enormous phylogenetic significance of internal transcribed spacer (ITS) sequence of nuclear ribosomal DNA (a gene which is nowadays considered better than its reputation) into consideration, this study was undertaken to resolve conflicts concerning the generic delimitations of Phytolaccaceae (s.l.).

\section{MATERIAL AND METHODS}

\section{Taxon sampling and selection of outgroup}

In the present study, we analyzed ITS sequences of nrDNA (including ITS1, 5.8S and ITS2) from 44 taxa [ 23 taxa newly sequenced in the present study, and 21 (including outgroup) taxa retrieved from GenBank] which covered representatives of 11 families of the order Caryophyllales. Leaf material representative of the genera Agdestis, Anisomeria, Gallesia, Gisekia, Hilleria, Ledenbergia, Microtea, Monococcus, Petiveria, Phytolacca, 
Rivinia, Schindleria, Seguieria, Stegnosperma, and Trichostigma. The visit for the sampling and herbarium consultation, at 'The Jepson Herbarium' (UC), University of California, Berkeley, CA, USA, were supported by research grant \#2011-00402 from the Ministry of Education, Science and Technology, Government of South Korea to J. Lee. CpDNA data have suggested a close relationship between the Nepenthaceae and Caryophyllales (Albert et al., 1992). Therefore, two species of Nepenthes ( $N$. alata and $N$. ventricosa; family Nepenthaceae) were employed as outgroup in the phylogenetic analyses. Voucher information and GenBank accession number for all taxa included in the analyses are listed in Table 1.

\section{Total genomic DNA extraction, amplification and sequencing}

Total DNA was extracted using the DNeasy Plant Mini kit (Qiagen, Valencia, CA, USA). ITS sequences of nrDNA were amplified using the ITS1 forward primer (5'-GTCCACTGAACCTTATCATTTAG-3') and ITS4 reverse primer (5'-TCCTCCGCTTATTGATATGC-3') of White et al. (1990) and AccuPower HF PCR PreMix (Bioneer, Daejeon, South Korea). One amplification round consisted of denaturation at $94^{\circ} \mathrm{C}$ for 5 min followed by 40 cycles of denaturation at $94^{\circ} \mathrm{C}$ for $1 \mathrm{~min}$, annealing at $49^{\circ} \mathrm{C}$ for $1 \mathrm{~min}$ and extension at $72^{\circ} \mathrm{C}$ for $1 \mathrm{~min}$, with a final extension at $72^{\circ} \mathrm{C}$ for $5 \mathrm{~min}$. The PCR products were purified with a SolGent PCR Purification kit-Ultra (SolGent, Daejeon, South Korea) before sequencing. The purified fragments were directly sequenced using dye terminator chemistry following manufacturer protocol. Cycle sequencing was conducted with the primers used for amplification, BigDye vers. 3 reagents and an ABI PRISM 3730XL DNA Analyzer (PerkinElmer, Applied Biosystems, USA) following the manufacturer instructions. Cycling conditions included initial denaturation at $94^{\circ} \mathrm{C}$ for $5 \mathrm{~min}$, followed by 30 cycles of $96^{\circ} \mathrm{C}$ for $10 \mathrm{~s}, 50^{\circ} \mathrm{C}$ for $5 \mathrm{~s}$, and $60^{\circ} \mathrm{C}$ for $4 \mathrm{~min}$. Each amplified product was sequenced in the sense and antisense direction. Nucleotide sequences of both DNA strands were obtained and analyzed using the ABI Sequence Navigator (Perkin-Elmer/Applied Biosystems, USA) to ensure accuracy. The boundaries between ITS1, 5.8S, and ITS2 for each sequence generated in the present study were determined and the sequences trimmed to extract the complete set of nrDNA ITS sequences by comparisons with the previously published related Caryophyllales sequences available in the GenBank database of National Center for Biotechnology Information (www.ncbi.nlm.nih.gov). All sequences generated in the present study were deposited in GenBank (Table 1).

\section{Sequence alignment and phylogenetic analyses}

Sequence alignment was performed using Clustal_X version 1.81 (Thompson et al., 1997). Insertion-deletions (Indels) were scored as single characters when we were confident of positional homology. Gaps were treated as missing data in phylogenetic analysis.

Maximum parsimony (MP) analysis was performed using PAUP* 4.0b10 (Swofford, 2002) with the following settings: heuristic search algorithms with tree bisection reconnecting (TBR) branch swapping, MULPARS in effect, all characters equally weighted, gap treated as missing characters, zero-length branches collapsed, random addition sequence set to 1000 replicates, and branch swapping limited to 10,000,000 rearrangements per replicate. When MP trees were saved, a strict consensus tree was constructed. Bootstrap analysis was performed using 1000 replicates, with the random addition sequence set to 10 , and branch swapping limited to $10,000,000$ rearrangements per replicate. 
Table 1. Taxa and accession examined in this study.

\begin{tabular}{|c|c|c|}
\hline Taxon & Voucher information & GenBank accession No. \\
\hline \multicolumn{3}{|l|}{ Ingroup } \\
\hline \multicolumn{3}{|l|}{ Aizoaceae } \\
\hline Acrodon purpureostylus Burgoyne* & South Africa, Thiede 110202 (BOL) & AJ577756 \\
\hline Aizoanthemum dinteri (Schinz) Friedrich* & Namibia, Hachfeld s.n. (HBG) & AJ577768 \\
\hline \multicolumn{3}{|l|}{ Basellaceae } \\
\hline Anredera cordifolia (Ten.) Steenis* & Stone s.n., IIII997 (DAV) & L78086 \\
\hline Basella alba $\mathrm{L} . *$ & California, USA, s.n. & L78018 \\
\hline Basella excavata Scott-Elliot* & Roeoesli s.n. 5 XI1992 (ZSS) & L78019 \\
\hline \multicolumn{3}{|l|}{ Didiereaceae } \\
\hline Alluaudia dumosa (Drake) Drake* & California, USA, Stone s.n., III1997 (DAV) & L78011 \\
\hline Alluaudia procera (Drake) Drake* & California, USA, s.n. & L78018 \\
\hline \multicolumn{3}{|l|}{ Molluginaceae } \\
\hline Limeum myosotis $\mathrm{H}$. Walter† & California, USA, R. Seydal 3422 (UC313548) & JX232591 \\
\hline Limeum pterocarpum (Gay) Heimerl† & South Africa, L.E Taylor 1071 (UC956465) & JX232592 \\
\hline \multicolumn{3}{|l|}{ Nyctaginaceae } \\
\hline Allionia choisyi Standl.* & Coahuila, Mexico, Douglas 2187 (DUKE) & EF079467 \\
\hline Mirabilis multiflora (Torr.) A. Gray* & Arizona, USA, Douglas 2037 (DUKE) & EF079452 \\
\hline Nyctaginia capitata Choisy* & New Mexico, USA, McIntosh 2049 (NMC) & EF079478 \\
\hline \multicolumn{3}{|l|}{ Phytolaccaceae (s.l.) } \\
\hline Agdestis clematidea Moc. \& Sessé ex DC. $\dagger$ & Mexico, USA, Ynes Mexin 8947 (UC645244) & JX232581 \\
\hline Anisomeria coriacea D. Don $\dagger$ & Chile, Worth \& Morrison 16564 (UC631904) & JX232582 \\
\hline Gallesia integrifolia (Spreng.) Harms $\dagger$ & Minas Gerais, USA, Hateschbach \& Silva 50394 (UC1558812) & JX232590 \\
\hline Gisekia africana Kuntze $\dagger$ & Gerstner 6330 (UC1589927) & JX232575 \\
\hline Gisekia pentadecandra Moq $\dagger$ & Transvaal, South Africa, Rodin 4227 (UC803496) & JX232574 \\
\hline Hilleria latifolia $($ Lam.) H. Walter $\dagger$ & Rio Huallaga, Bklshaw 3136 (UC1349624) & JX232576 \\
\hline Ledenbergia sequierioides Klotzsch ex Moq $\dagger$ & Venezuela, Curran \& Haman 1238 (UC924029) & JX232578 \\
\hline Microtea debilis $\mathrm{Sw} . \dagger$ & California, USA, Yuncker et al. 8647 (UC851834) & JX232577 \\
\hline Monococcus echinophorus $\mathrm{F}$. Muell. $\dagger$ & New Caledonia Franch 1130 (UC391190) & JX232579 \\
\hline Petiveria alliacea $\mathrm{L} . \dagger$ & Mexico, USA, C. A. Purpus 2272 (UC135654) & JX232580 \\
\hline Phytolacca americana $\mathrm{L} . \dagger$ & California, USA, D. W Taylor 7922 (JEPS112758) & JX232573 \\
\hline Phytolacca decandea $\mathrm{L} . \dagger$ & Tanganyika, Africa, Tanner 572 (UC178158) & JX232572 \\
\hline Phytolacca dioica $\mathrm{L} \cdot \dagger$ & Mexico, USA, Marquez et al. 38645 (UC1591219) & JX232571 \\
\hline Phytolacca icosandra $\mathrm{L}$. & Mexico, USA, J.H.Beaman 2749 (UC304752) & JX232570 \\
\hline Rivinia humilis L. $\dagger$ & Nicaragua, Narvaez 2523 (UC1393733) & JX232583 \\
\hline Schindleria weberbaueri O.C. Schmidt $\dagger$ & Peru, Goodspeed 9536 (UC647358) & JX232584 \\
\hline Seguieria coriacea Benth. $\dagger$ & Paraguae, Jan 3712 (UC940448) & JX232585 \\
\hline Stegnosperma cubense Nakai $\dagger$ & Mexico, USA, Nees \& Taylor 26589 (UC1582560) & JX232587 \\
\hline $\begin{array}{l}\text { Stegnosperma scandens (A. Rob. ex Lunan) } \\
\text { Standl. } \dagger\end{array}$ & Nicaragua, Neill 446 (UC14244366) & JX232586 \\
\hline Stegnosperma halimifolium Benth. $\dagger$ & Mexico, USA, Carter \& Kellog 2954 (UC095147) & JX232588 \\
\hline Trichostigma octandrum (L.) H. Walter† & s.n. (UC 000445) & JX232589 \\
\hline \multicolumn{3}{|l|}{ Polygonaceae } \\
\hline Polygonum hydropiper L.* & Mt. Kwanak, Seoul, Korea, Mun 701 (SNU) & U51275 \\
\hline Polygonum neofiliforme Nakai* & Mt. Chiri, Chungnam, Korea, Mun 23 (SNU) & U51273 \\
\hline Polygonum virginianum L.* & Virginia, Alexandria, USA, Suh 9402 (s.n.) & U51274 \\
\hline \multicolumn{3}{|l|}{ Portulacaceae } \\
\hline Calandrinia affinis Gill. ex Arn.* & Chile, Hershkovitz 92 (s.n.) & DQ090318 \\
\hline Calandrinia tricolor Phil.* & Chile, Hershkovitz 98-58 (CONC) & DQ090440 \\
\hline \multicolumn{3}{|l|}{ Sarcobataceae } \\
\hline Sarcobatus vermiculatus (Hook.) Torr.* & Nevada, USA, Spellenberg 13312 (NMC) & EF079501 \\
\hline \multicolumn{3}{|l|}{ Tamaricaceae } \\
\hline $\begin{array}{l}\text { Myricaria laxiflora (Franch.) P.Y. Zhang } \\
\text { \& Y.J. Zhang* }\end{array}$ & $\begin{array}{l}\text { Zitong, Banan, Chongqig, China, Yong Wang \& } \\
\text { Yifei Liu WY105 (HIB) }\end{array}$ & EU240610 \\
\hline Reaumuria soongarica (Pall.) Maxim.* & $\begin{array}{l}\text { Gonghe, Delingha, Qinghai, China, Yong Wang \& } \\
\text { Yifei Liu WY345 (HIB) }\end{array}$ & EU240611 \\
\hline Tamarix androssowii Litv.* & $\begin{array}{l}\text { Shapotou, Zhongwei, Ningxia, China, Yong Wang \& } \\
\text { Yifei Liu WY002 (HIB) }\end{array}$ & EU240612 \\
\hline \multicolumn{3}{|l|}{ Outgroup } \\
\hline \multicolumn{3}{|l|}{ Nepenthaceae } \\
\hline Nepenthes alata Blanco* & Mt. Guisguis, Zambales, Philippines, Lemana et al. 2001 (USTH) & AM690451 \\
\hline Nepenthes ventricosa Blanco* & Benguet Prov., Philippines, Madulid 775 (USTH) & AM269503 \\
\hline
\end{tabular}

†Indicates that the sequences were generated in the present study and submitted to GenBank; *indicates that the accession was obtained from GenBank. 


\section{RESULTS}

The combined length of the entire ITS region (ITS1, 5.8S and ITS2) from taxa analyzed in the present study ranged 556-681 nucleotides. The length of the ITS1 region and GC contents ranged 176-270 nucleotides and 47-76\%, respectively, the $5.8 \mathrm{~S}$ gene was $163 \mathrm{bp}$ long, and the length of the ITS2 region and the GC content ranged 206-249 nucleotides and $51-79 \%$, respectively. The data matrix consisted of a total number of 728 characters of which 198 characters were constant, 63 characters were variable but parsimony-uninformative, and 481 characters were parsimony-informative. Indels were necessary to align the sequences. Indels ranged from 1 to $35 \mathrm{bp}$. MP analysis of the entire ITS region resulted in 3540 maximally parsimonious trees (MPTs) (Figure 1). Maximum likelihood (ML) and Bayesian analyses were also performed, which recovered almost similar tree topology, and thus, only the MP topology is discussed here.

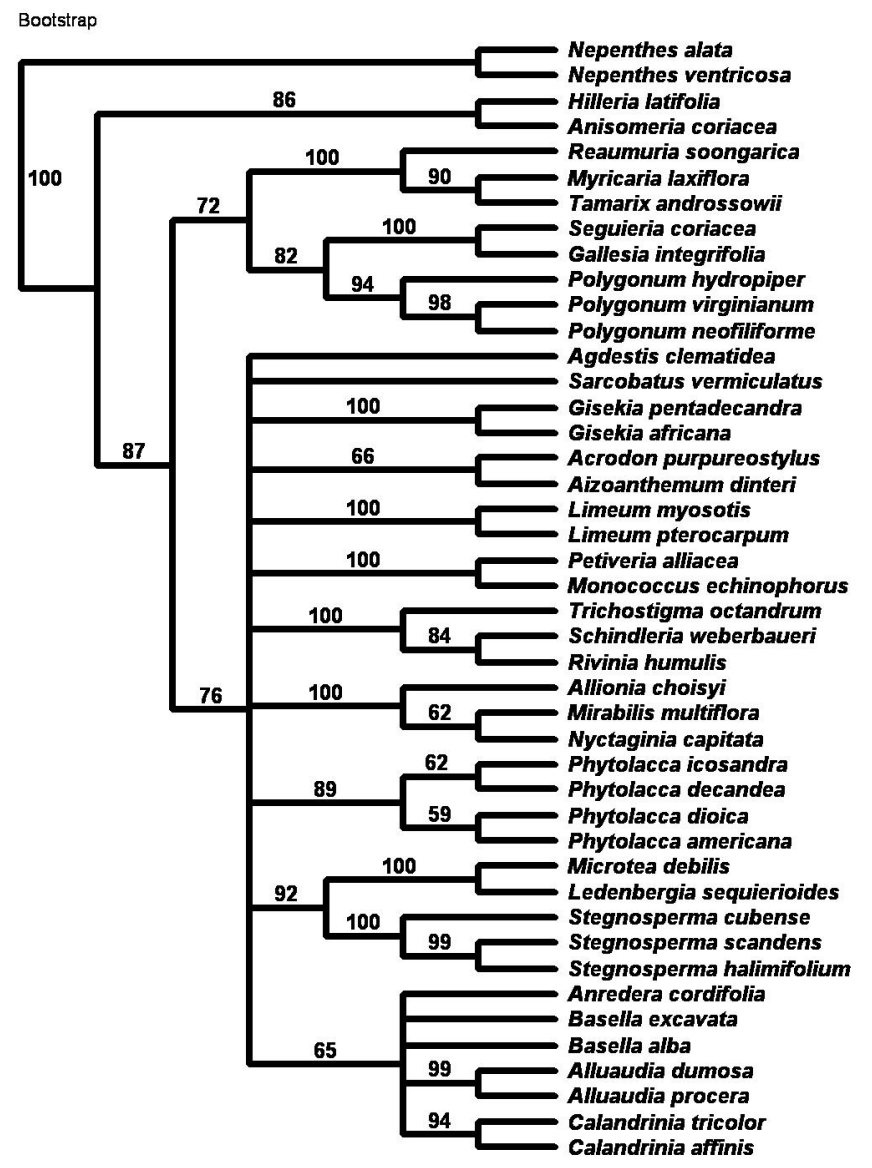

Figure 1. Bootstrap tree of 3540 maximally parsimonious trees (MPTs) with a total length of 3578 steps, a consistency index (CI) of 0.3502 ( $0.3338 \mathrm{CI}$ excluding uninformative characters), a homoplasy index (HI) of 0.6498 ( $0.6662 \mathrm{HI}$ excluding uninformative characters), rescaled consistency index of 0.1813 , and a retention index of 0.5177 . Bootstrap values greater than $50 \%$ in 1000 bootstrap replicates are shown above lines. 
MPTs resulting from the analysis of ITS sequences was strongly supported as a monophyletic group (bootstrap support 100\%) of the order Caryophyllales, with the relationships consistent with the $18 \mathrm{~S}$ rDNA, plastid $r b c L$, atpB, and matK phylogeny of Caryophyllales (Cuenoud et al., 2002); however, the members belonging to the family Phytolaccaceae $s . l$. did not cluster in a single clade. The MPTs resulting from the parsimony analysis resolved three major clade. Clade I (bootstrap support 86\%) consisted of Hilleria-Anisomeria (Phytolaccaceae s.l.). Clade II (bootstrap support 72\%) consisted of subclade (bootstrap support 100\%) Tamarix-Reaumuria-Myricaria (Tamaricaceae), and subclade (bootstrap support 82\%) SeguieriaGallesia (Phytolaccaceae s.l.) plus Polygonum (Polygonaceae) clade (bootstrap support 94\%). Clade III (bootstrap support 76\%) consisted of polytomies of Agdestis (Phytolaccaceae s.l.) an independent branch, Sarcobatus (Sarcobataceae) an independent branch, Gisekia (which has been variously placed in Aizoaceae, Molluginaceae, Gisekiaceae, or Phytolaccaceae s.l.), Acrodon-Aizoanthemum (Aizoaceae), Limeum (Molluginaceae), Petiveria-Monococcus (Phytolaccaceae s.l.), Trichostigma-Schindleria-Rivinia (Phytolaccaceae s.l.), Allionia-MirabilisNyctaginia (Nyctaginaceae), Phytolacca (Phytolaccaceae s.l.), Microtea-Ledenbergia (Phytolaccaceae s.l.), Stegnosperma (Stegospermataceae/Phytolaccaceae s.l.), and Anredera-Basella (Basellaceae)-Alluaudia (Didiereaceae)-Calandrinia (Portulacaceae). Clade I consisted of taxa absolutely treated under Phytolaccaceae s.l. only; however, the Seguieria-Gallesia (Phytolaccaceae s.l.) claded with the family Polygonaceae in clade II, and all other taxa belonging to Phytolaccaceae (s.l.) included in the analysis showed polytomies with the taxa from the various Caryophyllales families such as Sarcobataceae, Aizoaceae, Molluginaceae, Gisekiaceae, Nyctaginaceae, Stegospermataceae, Basellaceae, Didiereaceae, and Portulacaceae.

\section{DISCUSSION}

The genus Hilleria, consisting of four species (Mabberley, 2008) distributed from northern South America to Africa, has been previously treated under the Rivineae (Hermerl 1889, 1934), Petiveriaceae (Brown and Varadarajan, 1985), Phytolaccaceae (Cronquist, 1968, 1981; Takhtajan, 1969, 1980; Dahlgren, 1977, 1980), Rivinoideae (Nowicke, 1969), Petiverieae (Bortenschlager, 1973), and Rivioideae (Thorne, 1976, 1981). Hutchinson $(1959,1973)$ also treated the genus under Petiveriaceae but as a family under the order Pitosporales. The genus Anisomeria, with three species, has been described as being restricted from Chile to Argentina (Nowicke, 1969; Mabberley, 2008) and has been previously treated (Hermerl, 1889, 1934; Hutchinson, 1959, 1973; Cronquist, 1968, 1981; Takhtajan, 1969, 1980; Bortenschlager, 1973; Dahlgren, 1977, 1980; Brown and Varadarajan, 1985) under the family Phytolaccaceae and the Phytolaccoideae as well (Nowicke, 1969; Thorne, 1976, 1981). Morphologically, Hilleria and Anisomeria share certain similar morphological characters such as herbs or shrubs, inflorescences mostly terminal, spikes or spike-like racemes, flowers perfect, zygomorphic or not, sessile or pedicellate, bract single or absent, bracteoles 2 and fleshy, or absent, sepals united at the base, fruit drupelets or utricle, seed one, spermoderm wrinkled, sporoderm reticulated. These characters also overlap with those of other genera of Phytolaccaceae (s.l.).

In ITS phylogeny, the morphologically similar genera Seguieria and Gallesia claded (bootstrap support 100\%) with family Tamaricaceae and Polygonaceae (bootstrap support 72\%). Previously, both genera have been treated under either Phytolaccaceae, Petriveriaceae, Rivineae, Rivinoideae, Phytolaccoideae, Riviodeae, or Rivinioideae. Bortenschlager (1973) accommodated 
both Seguieria and Gallesia under Seguiereae of Petriveriaceae (see Brown and Varadarajan, 1985). Agdestis, a monotypic genus has been reported from Nicaragua, southern Florida and parts of Texas (Heimerl, 1934). Chemical and ultrastructural data have shown that Agdestis is properly placed in the Caryophyllales (Behnke et al., 1974). In the neighbor-joining tree (not shown here), Agdestis showed close relationships with Sarcobatus (Sarcobataceae). This relationship has also been reported in the phylogeny of Caryophyllales (Cuenoud et al., 2002). The habit, leaf shape and inferior ovary distinguish the genus Agdestis from all other members of the Phytolaccaceae (Nowicke, 1969). Though infrequently recognized as a segregate family from Phytolaccaceae (Dahlgren, 1977), Agdestis has routinely received monotypic tribal or subfamilial status (Nowicke, 1969; Bortenschlager, 1973). The Agdestidaceae are easily recognized by distinctive characters: association of twining herbs with a turnip-like rootstock, rounded, cordate leaves, apetalous, perigynous flowers with dorsifixed anthers and a syncarpous, multilocular, half-inferior ovary with one basal ovule per locule, achene-like and samaroid fruit due to four persistent calyx segments and one globose seed without aril. The present study strongly supports the previous treatment of the genus (Hutchinson, 1959, 1973; Dahlgren, 1977; Brown and Varadarajan, 1985), i.e., reorganization as the separate family Agdestidaceae under the order Caryophyllales.

In the past, Gisekia has been included in the Phytolaccaceae or Aizoaceae, often together with Molluginaceae or in a family of its own, Gisekiaceae. The detection of betalains in Gisekia reflects its close affinities to the Phytolaccaceae, a placement also supported by $r b c \mathrm{~L} / m a t \mathrm{~K}$ data (Cuenoud et al., 2002). As a result, Gisekia can be separated from Limeum a non-pigmented genus and the other genera of Molluginaceae containing only anthocyanins (Takhtajan, 1980; Brown and Varadarajan, 1985). Some authors treated Gisekia as a tribe (Gisekieae) in Aizoaceae (Müller, 1909; Pax and Hoffmann, 1934). Both Hutchinson (1959) and Eckardt (1964) included it again in Molluginaceae. Hofmann (1973), on the basis of corresponding gynoecium morphology, pointed out the relationship of Gisekia to Phytolaccaceae. However, most morphological and anatomical data underline that Gisekia is most closely related to Molluginaceae. Nakai (1942) was the first to create the monotypic family Gisekiaceae. The mericarpic fruit separates the genus from Aizoaceae and Molluginaceae, from which it also differs by the presence of betalains. None of the currently accepted plant family includes both anthocyanin and betalain producers. In the MPTs resulting from the present MP analysis, Gisekia did not nest with Phytolaccaceae or Aizoaceae, or even with Molluginaceae. Recently, acceptance of Gisekiaceae has gotten support from researchers (Gilbert, 2000). Seed morphology (Hassan et al., 2005) also supports the independent nature of Gisekia (Gisekiaceae).

Hutchinson $(1959,1973)$ treated the genus Petiveria under the family Petiveriaceae of Pitosporales along with Hilleria, Seguieria, Gallesia, Rivinia, Trichostigma, Schindleria, Ledenbergia, Monococcus, Lophiocarpus, and Microtea. Bortenschlager (1973) also followed the concept of Hutchinson $(1959,1973)$ but recognized the family Petiveriaceae under the order Caryophyllaes. However, Bortenschlager (1973) excluded Lophiocarpus from Petiveriaceae and treated it under a separate family, Lophiocarpaceae. Hermerl $(1889,1934)$, Cronquist (1968, 1981), Nowickce (1969), Takhtajan (1969, 1980), Thorne (1976, 1981), and Dahlgren $(1977,1980)$ did not recognize the family Petiveriaceae. Brown and Varadarajan (1985) considered the family Petiveriaceae with Gallesia, Hilleria, Ledenbergia, Petiveria, Rivina, Schindleria, Seguieria, and Trichostigma. Brown and Varadarajan (1985) also tentatively placed the genera Microtea, Lophiocarpus and Monococcus under Petiveriaceae. On 
the other hand, Petiveria, Hilleria, Seguieria, Gallesia, Rivinia, Trichostigma, Schindleria, Ledenbergia, Monococcus, Lophiocarpus, Microtea, and Phaulthamnus have been routinely treated under tribal or subfamily Rivineae (Heimerl, 1889, 1934), Rivinoideae (Nowicke, $1969)$ and Rivioideae Thorne $(1976,1981)$. On the basis of pollen morphology, Nowicke (1969) treated Microtea and Lophiocarpus under Microteoideae. In the 50\% majority rule tree and also in the neighbor-joining tree (not shown here), Petiveria and Monococcus clade together (bootstrap support 100\%) and are closely related to Phytolacca. However, the genera Trichostigma, Schindleria and Rivinia clade together (bootstrap support 100\%) and are distinct from the Petiveria-Monococcus clade. The genera Microtea and Ledenbergia also form a separate clade, independent from the Petiveria-Monococcus clade and Trichostigma, Schindleria, Rivinia clade. Microtea and Ledenbergia are closely related (bootstrap support 92\%) to Stegnosperma (Stegospermaceae). The family Stegospermaceae has also been recognized in the Angiosperm Phylogeny Group classification. On the basis of the present analysis, we support the reorganization of the family Petiveriaceae with two genera, i.e., Petiveria and Monococcus; however, grouping of Trichostigma, Schindleria, Rivinia under a single clade with strong support (bootstrap support 100\%) and grouping of Microtea and Ledenbergia in a separate clade independent from the Trichostigma-Schindleria-Rivinia clade, clades that are blended with members of Caryophyllales in MPTs, indicates the need for taxonomic recircumscription of Phytolaccaceae (s.l.) and further; the genera so- called anomalous phytolaccaceous members also need to be sequenced to infer their proximity under Caryophyllales.

\section{ACKNOWLEDGMENTS}

Research supported by the King Saud University, Deanship of Scientific Research, College of Science, Research Center.

\section{REFERENCES}

Albert VA, Williams SE and Chase MW (1992). Carnivorous plants: phylogeny and structural evolution. Science 257: 1491-1495.

Behnke HD (1994). Sieve-Element Plastids: Their Significance for the Evolution and Systematics of the Order. In: Caryophyllales: Evolution and Systematics (Behnke HD and Mabry TJ, eds.). Springer, Berlin, 87-121.

Behnke HD, Chang C, Eifert IJ and Mabry TJ (1974). Betalains and P-type sieve-tube plastids in Petiveria and Agdestis (Phytolaccaceae). Taxon 23: 541-542.

Bentham G and Hooker JD (1883). Genera Plantarum. Lovell, Reeve and Company, London.

Bessey CE (1915). The phylogenetic taxonomy of flowering plants. Ann. Miss. Bot. Gard. 2: 109-164.

Bittrich V (1993). Introduction to Centrospermae. In: The Families and Genera of Vascular Plants, Magnoliid, Hamamelid, and Caryophyllid Families (Kubitzki K, Rohwer JG and Bittrich V, eds.). Springer, Berlin, 13-19.

Bortenschlager S (1973). Morphologie pollinique des Phytolaccaceae. Pollen \& Spores 15: 227-253.

Brown GK and Varadarajan GS (1985). Studies in Caryophyllales I: Re-evaluation of Classification of Phytolaccaceae s.1. Syst. Bot. 10: 49-63.

Brown NE (1909). Flora of Ngamiland. Royal Botanic Gardens, Kew, 81-146.

Clement JS, Mabry TJ, Wyler H and Dreiding SA (1994). Chemical Review and Evolutionary Significance of Betalains. In: Caryophyllales: Evolution and Systematics (Behnke HD and Mabry TJ, eds.). Springer, Berlin, 247-261.

Cronquisat A (1968). The Evolution and Classification of Flowering Plants. Houghton Mifflin Com., Boston.

Cronquist A (1981). An Integrated System of Classification of Flowering Plants. Columbia University Press, New York.

Cronquist A and Thorne RF (1994). Nomenclatural and Taxonomic History. In: Caryophyllales: Evolution and Systematics (Behnke HD and Mabry TJ, eds.). Springer, Berlin, 87-121.

Cuenoud P, Savolainen V, Chatrou LW, Powell M, et al. (2002). Molecular phylogenetics of Caryophyllales based on 
nuclear 18S rDNA and plastid $r b c L$, atpB, and matK DNA sequences. Am. J. Bot. 89: 132-144.

Dahlgren R (1977). A commentary on a diagrammatic presentation of the angiosperms in relation to the distribution of character states. Plant Syst. Evol. (Suppl 1): 253-283.

Dahlgren RMT (1980). A revised system of classification of the angiosperms. Bot. J. Linn. Soc. 80: 91-124.

Downie S, Katz-Downie D and Cho K (1997). Relationships in the Caryophyllales as suggested by phylogenetic analyses of partial chloroplast DNA ORF2280 homolog sequences. Am. J. Bot. 84: 253.

Eckardt T (1964). Reihe Centrospermae. In: Syllabus der Pflanzenf 12 (2) (Engler A, ed.). Gebruder Borntraeger, Berlin, 79-102.

Gilbert MG (2000). Gisekiaceae. In: Flora of Ethiopia and Eritrea (Edwards SB, Tadese M, Demisssew S and Hedberg I, eds.). The National Herbarium and Uppsala, The Department of Systematic Botany, Addis Ababa, 238-239.

Hassan NM, Meve U and Liede-Schumann S (2005). Seed coat morphology of Aizoaceae-Sesuvioideae, Gisekiaceae and Molluginaceae and its systematic significance. Bot. J. Linn. Soc. 148: 189-206.

Heimerl A (1889). Phytolaccaceae. In: Die Natürlichen Pflanzenfamilien III, 1 b (Engler A and Prantl K, eds.). Wilhelm Engelmann, Leipzig, 1-14.

Heimerl A (1934). Phytolaccaceae. In: Die Natürlichen Pflanzenfamilien (Engler A and Prantl K, eds.). 2nd edn. Wilhelm Engelmann, Leipzig, 135-164.

Hofmann U (1973). Morphologische untersuchungen zur umgrenzung und gliederung der aizoaceen. Botanische Jahrbücher für Systematik, Pflanzengeschichte und Pflanzengeographie 93: 247-324.

Hutchinson J (1959). The Families of Flowering Plants. 1. Dictotyledons, 2nd ed. Oxford University Press, London.

Hutchinson J (1973). The Families of Flowering Plants, 3rd ed. Clarendon Press, Oxford.

Mabberley DJ (2008). The Plant-Book. Cambridge University Press, Cambridge.

Müller K (1909). Beiträge zur systematik der aizoaceen. Botanische Jahrbücher für Systematik, Pflanzengeschichte und Pflanzengeographie. 42 (Beibl. 97): 54-94.

Nakai T (1942). Notulae ad plantas Asiae orientalis. J. Jap. Bot. 18: 91-120.

Nowicke JW (1969). Palynotaxonomic study of the Phytolaccaceae. Ann. Miss. Bot. Gard. 55: 294-364.

Pax F and Hoffmann K (1934). Aizoaceae In: Die Natürlichen Pflanzenfamilien (Engler A and Prantl K, eds.). 2nd edn. Engelmann, Leipzig, 179-233.

Swofford DL (2002). PAUP: Phylogenetic Analysis Using Maximum Parsimony (and Other Method). Version 4.0b10. Sinauer, Sunderland.

Takhtajan A (1969). Flowering Plants. Origin and Dispersal. Smithsonian Institution Press, Washington.

Takhtajan AL (1980). Outline of the classification of flowering plants (Magnoliophyta). Bot. Rev. 46: 225-359.

Thompson JD, Gibson TJ, Plewniak F, Jeanmougin F, et al. (1997). The CLUSTAL_X windows interface: flexible strategies for multiple sequence alignment aided by quality analysis tools. Nucleic Acids Res. 25: 4876-4882.

Thorne RF (1976). A phylogenetic classification of the Angiospermae. Evol. Biol. 9: 35-106.

Thorne RF (1981). Phytochemistry and Angiosperm Phylogeny: A Summary Statement. In: Phytochemistry and Angiosperm Phylogeny (Young DA and Seigler DS, eds.). Praeger Scientific Press, New York, 57-94.

Walter H (1909). Phytolaccaceae. In: Pflanzenreich 4, 83 (Engler A, ed.). W. Engelmann, Leipzig, 1-154.

White TJ, Bruns T, Lee S and Taylor J (1990). Amplification and Direct Sequencing of Fungal Ribosomal RNA Genes for Phylogenetics. In: PCR Protocols: A Guide to Method and Amplifications (Innis MA, Gelfand DH, Sninksky JJ and White TJ, eds.). Academic Press, San Diego, 315-322. 